Effect of pruning frequency and pruning height on the biomass production of

Tithonia diversifolia (Hemsl) A. Gray

Samuel T. Partey

Agroforestry Systems

An International Journal incorporating Agroforestry

Forum

ISSN 0167-4366

Agroforest Syst

DOI 10.1007/s10457-010-9367y

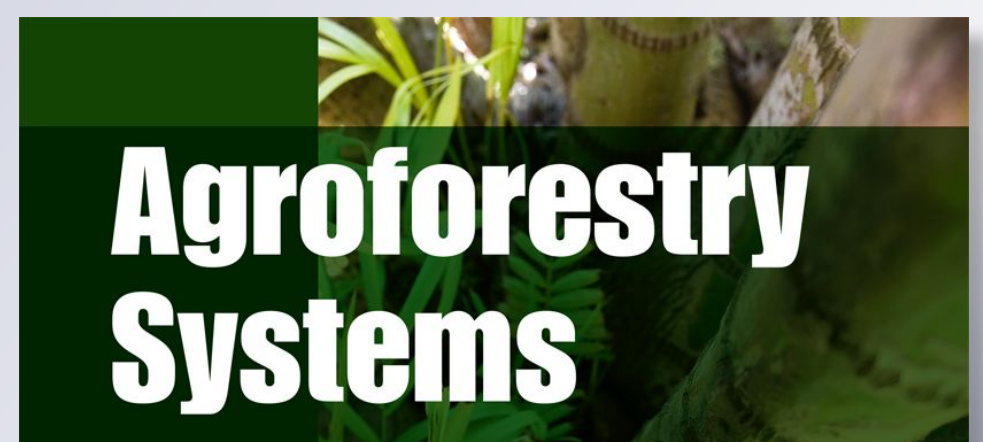

An international journal in cooperation with ICRAF

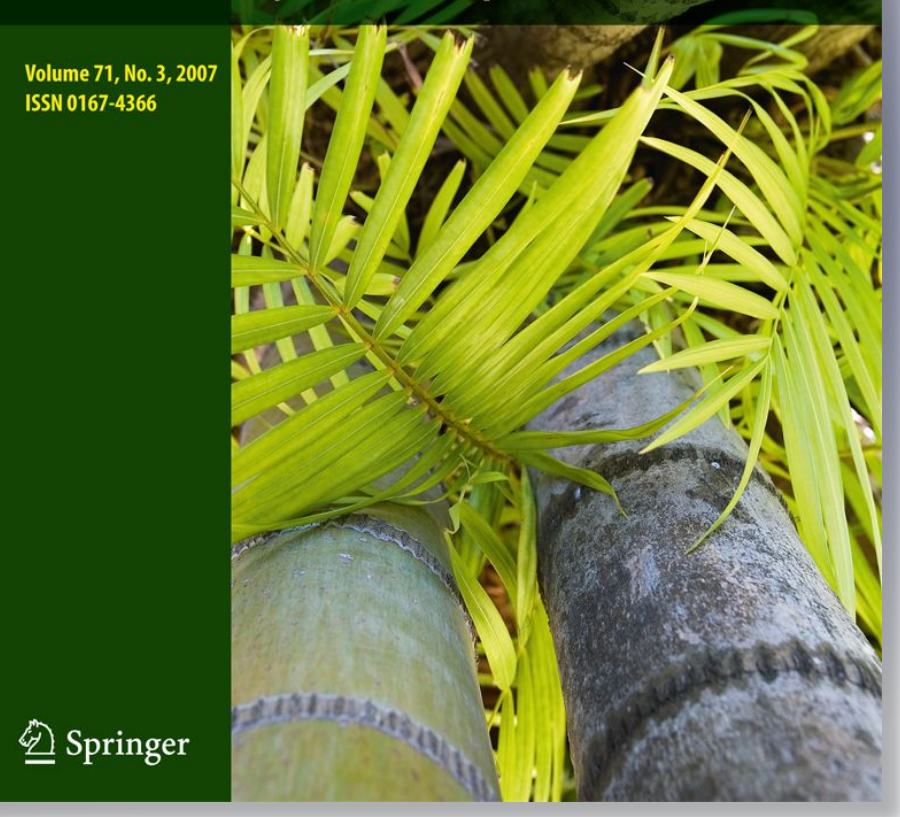

包 Springer 
Your article is protected by copyright and all rights are held exclusively by Springer Science+Business Media B.V.. This e-offprint is for personal use only and shall not be selfarchived in electronic repositories. If you wish to self-archive your work, please use the accepted author's version for posting to your own website or your institution's repository. You may further deposit the accepted author's version on a funder's repository at a funder's request, provided it is not made publicly available until 12 months after publication. 


\title{
Effect of pruning frequency and pruning height on the biomass production of Tithonia diversifolia (Hemsl) A. Gray
}

\author{
Samuel T. Partey
}

Received: 19 July 2010/Accepted: 21 December 2010

(C) Springer Science+Business Media B.V. 2011

\begin{abstract}
Addition of tree or shrub prunings through alley cropping or biomass transfer systems have contributed to sustainable land-use systems in the tropics. Long term productivity of biomass transfer systems require shrub or tree species that coppice after cutting to provide sufficient plant nutrients. The effect of pruning frequency and cutting height on the biomass production of Tithonia diversifolia was studied to provide information for managing hedges. Results showed that height of cutting, pruning frequency, and their interactions significantly affected dry matter production of $T$. diversifolia. The results also showed that a significantly higher biomass production could be produced when Tithonia was pruned at long time intervals. Pruning height was also of importance in the harvesting of Tithonia biomass and it was evident that dry matter production was highest when Tithonia was pruned bimonthly at $50 \mathrm{~cm}$ height. With bi-monthly pruning frequency, dry matter production could be as high as $7.2 \mathrm{t} \mathrm{ha}^{-1} \mathrm{yr}^{-1}$ which might be a sufficient biomass to improve soil productivity in biomass transfer systems.
\end{abstract}

Keywords Soil fertility - Biomass production . Plant management $\cdot$ Agroforestry

S. T. Partey ( $\square)$

Faculty of Life Sciences, University of Manchester,

Michael Smith Building, Oxford Road,

Manchester M13 9PT, UK

e-mail: sammtech147@yahoo.co.uk

\section{Introduction}

Declining soil fertility remains the fundamental reason for declining smallholder food production in sub-Saharan Africa even when improved germplasm has become available (Gruhn et al. 2000; Smaling et al. 1997). This poses threats to food security and livelihoods of the populations in the region. Although some efforts have been made in making inorganic fertilizers affordable to farmers (such as provision of subsidies for fertilizer purchase), the resource-poor farmers are unable to meet fertilizer requirements for their farms. Farmers are therefore faced with increasing difficulties in their attempts to maintain high productivity in intensively cropped farms.

The application of organic materials such as tree or shrub prunings with relatively high nutrient composition and fast decomposition properties have been recommended either as sole soil amendments or in combination with mineral fertilizers (Gachengo et al. 1999; Nziguheba et al. 2000; Quinkenstein et al. 2009). The addition of these tree or shrub prunings through alley cropping or biomass transfer systems have made substantial contributions to the development of sustainable land-use systems in the tropics by providing a cost-effective mechanism for optimizing crop yields for efficient and stable crop production (Kang 1997; Young 1997). These systems combine the regenerative properties of bush fallow system (Nye and Greenland 1960) with herbaceous crop production. The periodic pruning and return of 
residues from hedgerow trees or shrubs through alley cropping or biomass transfer, contribute to recycling of plant nutrients, improvements in soil temperature, enhancement of soil structure, erosion control, and maintenance of microbial activity and high soil nutrient status (Isaac et al. 2003; Lin et al. 2009; Wang et al. 2010). This enhancement is crucial in many areas of the humid and sub-humid tropics dominated by soils of low cation exchange capacity-the so-called low-acidity clay soils that may quickly lose their fertility if fallow periods, or some analog to fallow conditions, are not imposed (Kang 1991). Moreover, long term productivity of alley cropping or biomass transfer systems require shrub or tree species that can coppice vigorously after each cutting (Latt et al. 2000). With many of the soil fertility and nutrient cycling benefits of agroforestry systems derived from the production and decomposition of tree biomass (Nair et al. 1999), optimal biomass production would be expected at each cutting to provide sufficient amount of nutrients to meet crop nutrient demands (Latt et al. 2000).

Investigations of the effect of cutting frequency and cutting height on coppicing and biomass production have been undertaken and differences in production due to various cutting regimes have been found with many species such as Leucaena leucocephala and Gliricidia sepium (Guevarra et al. 1978; Latt et al. 2000) and not Tithonia diversifolia. Addition of biomass obtained from $T$. diversifolia has been shown to improve crop yields and enhance nutrient availability (Cong and Merckx 2005; Gachengo et al. 1999; Ikerra et al. 2006; Jama et al. 2000). Although T. diversifolia has confirmed potential for biomass transfer (Gachengo et al. 1999; Jama et al. 2000), little is known if its biomass production is influenced by different pruning regimes and pruning heights. Considering the importance of such information in the management of $T$. diversifolia hedges, this study was conducted to assess the effect of pruning frequency and cutting height on biomass production of $T$. diversifolia.

\section{Materials and methods}

The study was conducted at the Department of Horticulture of the Kwame Nkrumah University of Science and Technology, Kumasi (KNUST), Ghana. The area falls within the moist semi-deciduous forest zone of Ghana and receives a bimodal rainfall, with the major wet season between May and July. This area experiences two dry periods: in August and in December to March. The annual rainfall ranges between 1200 to $1500 \mathrm{~mm}$ with a mean annual temperature of $26.6^{\circ} \mathrm{C}$ and a mean annual humidity of $67.6 \%$. The soils are classified as ferric acrisol (FAO 1988) with a sandy-loam textural class.

Experimental design and sampling procedure

Established stands of $T$. diversifolia at the Department of Horticulture, KNUST were used for this experiment. Tithonia plants used in the experiment were 5 years old before biomass harvests began in 2008. Tithonia plants were planted at a $1 \mathrm{~m} \times 1 \mathrm{~m}$ spacing with ten (10) plants per treatment. Treatments were separated by a row of five Tithonia plants as buffers. The experiment was arranged in a splitplot design with treatments randomly arranged in four blocks. Treatments consisted of three cutting heights (which were 25, 50 and $100 \mathrm{~cm}$ above the ground and coded as $\mathrm{H} 1, \mathrm{H} 2$, and $\mathrm{H} 3$ respectively) and three cutting frequencies (2-, 4-, and 8-week interval as F1, $\mathrm{F} 2$, and $\mathrm{F} 3$ respectively). Cutting height $(\mathrm{CH})$ represented whole-plot treatments whilst pruning frequency (PF) was designated as sub-plot treatment.

When the study began, mean shrub height was $2.3 \mathrm{~m}$. All Tithonia plants were initially cut back to the designated cutting height treatment and the pruning frequency treatments were subsequently imposed. At each subsequent cutting, all coppice sprouts on the stumps were cut back to within $1 \mathrm{~cm}$ of the stump. Number of shoots and fresh weight of the coppice production (green stems and leaves) were recorded after each cutting. Subsamples from each plot were taken to the laboratory and oven-dried at $65^{\circ} \mathrm{C}$ to constant weight. Percentage dry weight of the original fresh weight was used to determine total plot dry matter. Yield (production) assumed a plant density of 5000/ha (which is derived from a typical alley cropping spacing of $0.5 \mathrm{~m} \times 4 \mathrm{~m}$ ) (Erdmann et al. 1993).

Data on shoot number and dry matter production were analyzed using general analysis of variance procedures in GENSTAT 11.1 (VSN International 2008). Treatment means were compared using least significant difference $(P=0.05)$. Multiple linear regression models were fitted to determine if cutting 
frequency and cutting height were significantly $(P=0.05)$ correlated to shoot development and dry matter production.

\section{Results}

Shoot number

Pruning frequency and its interaction with cutting height significantly $(P<0.001)$ influenced mean shoot number. Shoot production tended to be highest (19.7) at $\mathrm{H} 2$ and lowest (17.3) at $\mathrm{H} 3$. With respect to pruning frequency, mean number of shoots decreased with decreasing pruning frequency: F3 $(14.7)<$ F2 $(18)<$ F1 (22.3). The cutting height by pruning frequency interaction, indicated that pruning frequencies F1, F2, and F3 favoured shoot production in $\mathrm{H} 2$, $\mathrm{H} 1$, and $\mathrm{H} 3$ respectively (Fig. 1). Multiple regression analysis showed there was a significant correlation $\left(P<0.001, r^{2}=0.64\right)$ between pruning frequency and shoot production.

\section{Biomass production}

Analysis of variance test showed significant $(P<0.001)$ effect of pruning frequency, cutting height, and their interaction on the dry matter production of $T$. diversifolia. Regardless of cutting

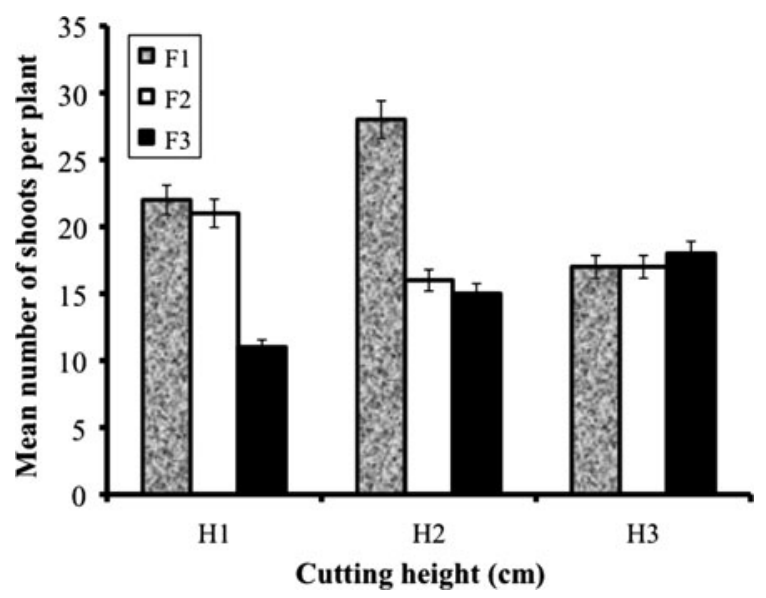

Fig. 1 Mean number of shoots as affected by pruning frequency $(\mathrm{F} 1=2$-week interval, $\mathrm{F} 2=4$-week interval, $\mathrm{F} 3=8$-week interval) and cutting height $(\mathrm{H} 1=25 \mathrm{~cm}, \mathrm{H} 2=50 \mathrm{~cm}, \mathrm{H} 3=$ $100 \mathrm{~cm}$ ). Data points are the means of four replicates. Error bars represent standard error of means heights and pruning frequencies, dry matter content (in leaves + stems) was estimated to be $(15 \pm 5) \%$ of fresh weight. All pruning height treatments markedly decreased biomass production from the 2nd to the 8th week of the experiment at F1 (Fig. 2). Although there was a rise in biomass production (particularly at $\mathrm{H} 3$ ) after 8 weeks, signs of mortality were prevalent among treatments after 12 weeks.

Patterns of dry matter production at F2 were quite consistent with F1 during the first 16 weeks of the experiment (Fig. 3). Biomass production fell to

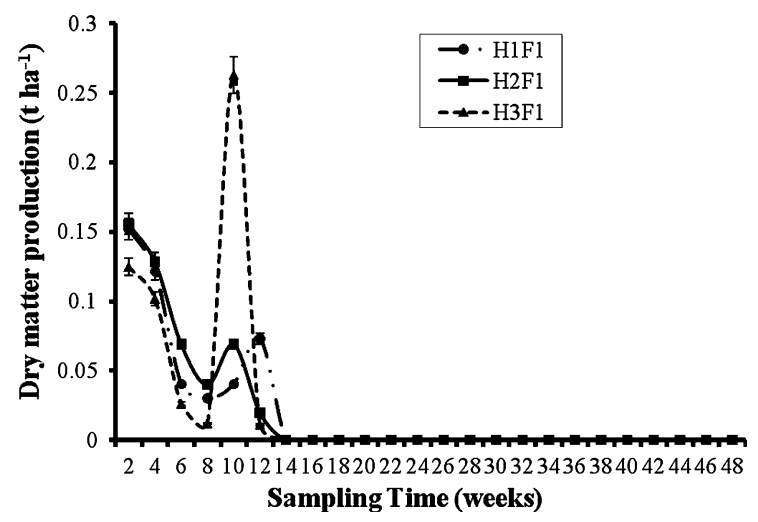

Fig. 2 Dry matter production of $T$. diversifolia as influenced by cutting height $(\mathrm{H} 1=25 \mathrm{~cm}, \mathrm{H} 2=50 \mathrm{~cm}$ and $\mathrm{H} 3=$ $100 \mathrm{~cm}$ ) at two-week (F1) pruning frequency over 48 weeks. Data points are the means of four replicates. Error bars represent standard error of means

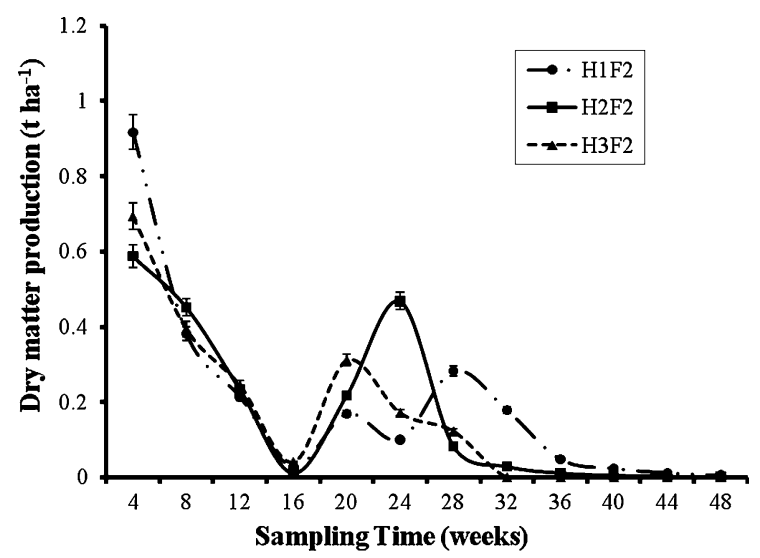

Fig. 3 Dry matter production of $T$. diversifolia as influenced by cutting height $(\mathrm{H} 1=25 \mathrm{~cm}, \mathrm{H} 2=50 \mathrm{~cm}$ and $\mathrm{H} 3=$ $100 \mathrm{~cm}$ ) at four-week (F2) pruning frequency over 48 weeks. Data points are the means of four replicates. Error bars represent standard error of means 


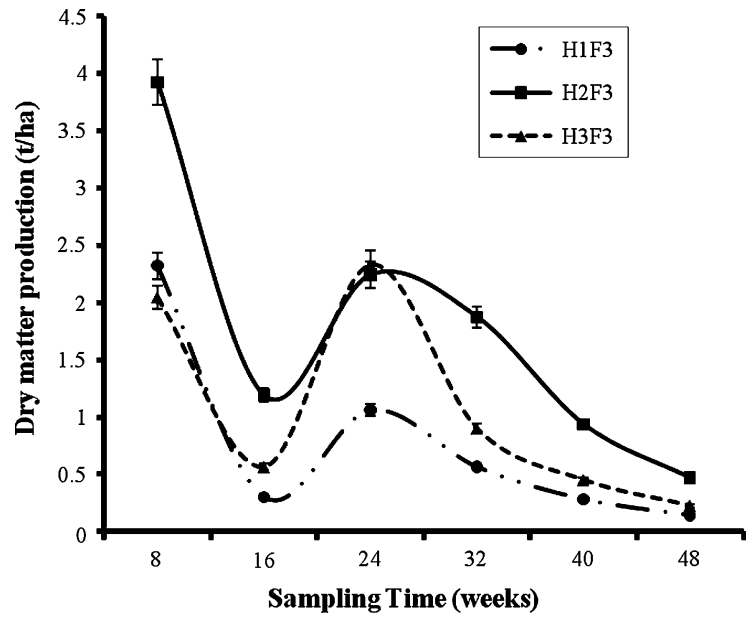

Fig. 4 Dry matter production of $T$. diversifolia as influenced by cutting heights $(\mathrm{H} 1=25 \mathrm{~cm}, \mathrm{H} 2=50 \mathrm{~cm}$ and $\mathrm{H} 3=$ $100 \mathrm{~cm}$ ) at eight-week (F3) pruning frequency over 48 weeks. Data points are the means of four replicates. Error bars represent standard error of means

nearly zero following three times of pruning. Conversely, 'stump-life' or survival tended to be longer (approximately 40 weeks) in stumps pruned at F2. The pattern of dry matter production at F3 was similar among all pruning heights (Fig. 4). There was a drastic decline in dry matter production from 8 to 16 weeks, which then increased sharply to 24 weeks and then decreased gradually till the 48th week. Polynomial models describing the cumulative dry matter production of $T$. diversifolia as influenced by the interactive effect of pruning frequency and cutting height (Figs 2, 3, 4) are shown in Table 1.

Table 1 Polynomial models for cumulative dry matter production of $T$. diversifolia as influenced by pruning frequency and cutting height

\begin{tabular}{lll}
\hline Treatment & Polynomial model & $R^{2}$ \\
\hline H1F1 & $Y=-0.0003 x^{2}+0.017 x+0.22$ & 0.80 \\
H2F1 & $Y=-0.0003 x^{2}+0.017 x+0.25$ & 0.73 \\
H3F1 & $Y=-0.0004 x^{2}+0.027 x+0.16$ & 0.77 \\
H1F2 & $Y=-0.011 x^{2}+0.267 x+0.72$ & 0.98 \\
H2F2 & $Y=-0.018 x^{2}+0.367 x+0.27$ & 0.97 \\
H3F2 & $Y=-0.018 x^{2}+0.336 x+0.43$ & 0.98 \\
H1F3 & $Y=-0.07 x^{2}+1.007 x+1.22$ & 0.97 \\
H2F3 & $Y=-0.158 x^{2}+2.552 x+1.21$ & 0.98 \\
H3F3 & $Y=-0.165 x^{2}+2.135 x-0.26$ & 0.96 \\
\hline
\end{tabular}
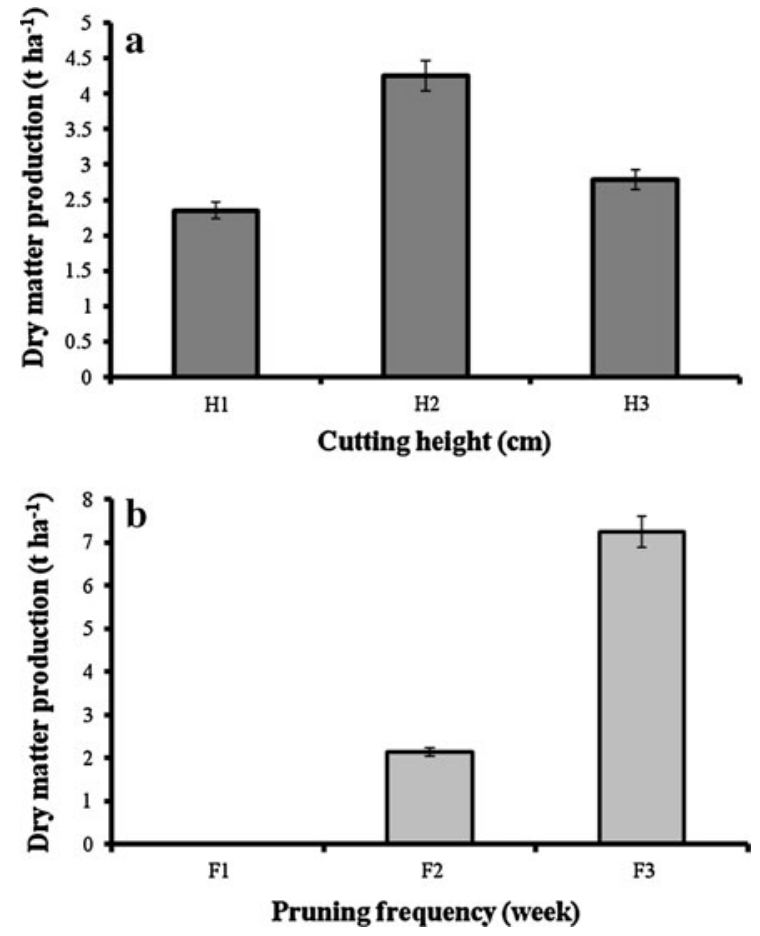

Fig. 5 Dry matter production of $T$. diversifolia as affected by cutting height $(\mathrm{H} 1=25 \mathrm{~cm}, \mathrm{H} 2=50 \mathrm{~cm}$ and $\mathrm{H} 3=100 \mathrm{~cm}$ of cuttings) (a) and pruning frequency ( $\mathrm{F} 1=2$-week interval, F2 $=4$-week interval, F3 = 8-week interval) (b). Data points are the means of four replicates. Error bars represent standard error of means

Dry matter production rate as shown by the slope of the curves described in Table 1 was highest in H3, $\mathrm{H} 2$, and again $\mathrm{H} 2$ for pruning frequencies, F1, F2, and F3 respectively. Among cutting heights, mean dry matter production was highest $\left(4.3 \mathrm{t} \mathrm{ha}^{-1}\right)$ in $\mathrm{H} 2$ and lowest $\left(2.3 \mathrm{t} \mathrm{ha}^{-1}\right)$ in H1 (Fig. 5a). Regardless of cutting height, dry matter production generally decreased with increasing pruning frequency (Fig. 5b). Among cutting height and pruning frequency interaction, biomass production was highest in $\mathrm{H} 2 \mathrm{~F} 3$ and lowest in H1F1. Biomass production for F1 was low compared to F2 and F3. In addition, dry matter production in plants pruned at F3 was approximately 3 times that of plants pruned at F2 (Table 2). Regardless of cutting height, mean dry matter production was $7.2 \mathrm{t} \mathrm{ha}^{-1}$ when $T$. diversifolia was pruned at F3. Multiple regression analysis showed there was a significant $\left(P<0.001, r^{2}=\right.$ 0.19 ) correlation between pruning frequency and dry matter production. 
Table 2 Total dry matter production of $T$. diversifolia as affected by the interaction between pruning frequency and cutting height over 48 weeks

\begin{tabular}{lc}
\hline Treatment & $\begin{array}{l}\text { Total dry matter } \\
\text { production }\left(\mathrm{t} \mathrm{ha}^{-1}\right)\end{array}$ \\
\hline $\mathrm{H} 1 \mathrm{~F} 1$ & 0.0046 \\
$\mathrm{H} 2 \mathrm{~F} 1$ & 0.0048 \\
$\mathrm{H} 3 \mathrm{~F} 1$ & 0.0054 \\
$\mathrm{H} 1 \mathrm{~F} 2$ & 2.36 \\
$\mathrm{H} 2 \mathrm{~F} 2$ & 2.10 \\
$\mathrm{H} 3 \mathrm{~F} 2$ & 1.98 \\
$\mathrm{H} 1 \mathrm{~F} 3$ & 4.68 \\
$\mathrm{H} 2 \mathrm{~F} 3$ & 10.64 \\
$\mathrm{H} 3 \mathrm{~F} 3$ & 6.52 \\
LSD & 0.05 \\
C.V. $(\%)$ & 6.8 \\
\hline
\end{tabular}

$\mathrm{F} 1=2$-week interval, $\mathrm{F} 2=4$-week interval, $\mathrm{F} 3=8$-week interval, $\mathrm{H} 1=25 \mathrm{~cm}, \mathrm{H} 2=50 \mathrm{~cm}, \mathrm{H} 3=100 \mathrm{~cm}$

\section{Discussions and conclusion}

Cutting height, pruning frequency, and their interaction significantly influenced dry matter production of T. diversifolia. Similar studies with $T$. diversifolia are rare. While similar studies have been conducted with G. sepium and L. leucocephala, it is often difficult to compare biomass production of agroforestry shrubs in one study to another as plant age, cutting height, plant density, percent dry matter of fresh weight, and plant part weighed (i.e. leaves, green stems, or woody stems) may differ. Dry matter production of G. sepium and L. leucocephala increased with increasing pruning height and decreasing pruning frequency (Duguma et al. 1988). A follow-up experiment (Erdmann et al. 1993) did not confirm the effect of cutting height on biomass production. Discrepancies between tests were attributed to sampling errors and did not dispute the assertion that increasing cutting height increased biomass production (Duguma et al. 1988). Even though dry matter production in this study did not strictly increase from $\mathrm{H} 1$ to H3, it was evident that dry matter production at $\mathrm{H} 2$ and $\mathrm{H} 3$ were significantly higher than at $\mathrm{H} 1$ (the lowest cutting height), which might support an hypothesis that increasing cutting height increased dry matter production.

The hypothesis that frequent cutting decreases biomass production in agroforestry trees (Latt et al. 2000) was confirmed by this study. Several studies have demonstrated that increased frequency of cutting decreases subsequent biomass production in woody species used in tropical alley cropping systems (Duguma et al. 1988; Ella et al. 1989; Guevarra et al. 1978). Although this experiment did not investigate the dynamism in reserve carbohydrates and soluble sugar with increasing pruning frequency, biomass production in many agroforestry species has been related to reserve carbohydrates which are major influential factors of biomass production in plants. According to Harrington (1989), repeated defoliation of plants at short intervals depleted reserve carbohydrates. Harrington's assertion was in support of observations made by Latt et al. (2000) when they studied the interactions among cutting frequency, reserve carbohydrates, and post-cutting biomass production in G. sepium and L. leucocephala in Ibadan, Nigeria. They observed from their study that frequent cutting progressively decreased concentrations of starch and total reserve carbohydrates in G. sepium and L. leucocephala which was also linearly correlated to dry matter production. The evidence strongly supports the idea that plants mobilize reserve carbohydrates to rebuild photosynthetic tissue after cutting, defoliation, or seasonal loss of foliage. It is therefore reasonable to assume that if trees are cut too frequently; carbohydrate reserves will be progressively depleted unless sufficient time for replenishment is allowed between cuts (Latt 1996). This intermittent interruption of temporal cycles of carbohydrate reserves owing to increased pruning frequency may therefore account for the decreased dry matter production in T. diversifolia.

The ability of trees in early-successional agroforestry systems to coppice after being cut or pruned is important since many of the soil-fertility and nutrientcycling benefits of agroforestry systems are derived from the decomposition and release of plant nutrients from tree biomass (Latt et al. 2000; Nair et al. 1999). As observed in this study, frequent prunings negatively affected the survival of $T$. diversifolia stands. With bi-weekly pruning frequency, about $90 \%$ mortality was recorded within 3 weeks for all pruning heights. The strong negative effect of frequent pruning on the survival of $T$. diversifolia stands may in part be due to the age of the plants used in this trial. Chadhokar (1982) and Duguma et al. (1988) observed that frequent cuttings in the year of establishment had a negative effect on Gliricidia yield in later years. 
Further studies are needed to determine if the effect of pruning height is the same for older and more established stands than those used in this experiment. Following the above observations, the management of $T$. diversifolia would require prudent decisions on when to harvest the biomass. The results showed that more biomass was produced when $T$. diversifolia was pruned at long pruning intervals. Pruning height was also of importance in the harvesting of the biomass as shoot and dry matter production were greatest when $T$. diversifolia was pruned at $50 \mathrm{~cm}$ height. This height would be comfortable to farmers as they would not have to bend so much. With a bi-monthly pruning frequency (F2), dry matter production could be as high as $7.2 \mathrm{t} \mathrm{ha}^{-1} \mathrm{yr}^{-1}$. While data obtained from the study have provided a general relationship between pruning frequency, pruning height, and biomass production, conclusions may be specific to the age of plants and the geographical region. Caution must be taken in making yield predictions for different ages and climatic regions.

Acknowledgments I wish to express my sincere gratitude to Tropenbos International, Ghana and the Kwame Nkrumah University of Science and Technology, Kumasi, Ghana who provided funds to carry-out this project during my postgraduate studies. I also thank Prof. S. J. Quashie-Sam and Dr. J. J. Afuakwa of KNUST for their review and remarkable contributions. The efforts of all anonymous reviewers and Dr. Dave Burner (Associate Editor, Agroforestry Systems) are very well appreciated.

\section{References}

Chadhokar PA (1982) Gliricidia maculata a promising legume fodder plant. World Anim Rev 44:36-43

Cong PT, Merckx R (2005) Improving phosphorus availability in two upland soils of Vietnam using $T$. diversifolia $\mathrm{H}$. Plant Soil 269:11-23

Duguma B, Kang BT, Okali DUU (1988) Effect of pruning intensity of three woody leguminous species grown in alley cropping with maize and cowpea on an alfisol. Agrofor Syst 6:19-35

Ella A, Jacobsen C, Stür WW, Blair G (1989) Effect of plant density and cutting frequency on the productivity of four tree legumes. Trop Grasslands 23:28-34

Erdmann TK, Nair PKR, Kang BT (1993) Effects of cutting frequency and cutting height on reserve carbohydrates in Gliricidia sepium (Jacq.) Walp. For Ecol Manag 57:45-60

FAO (1988) FAO-UNESCO Soil map of the world. Revised legend. Reprinted with corrections. World soil resources report 60. FAO, Rome
Gachengo CN, Palm CA, Jama B, Othieno C (1999) Tithonia and Senna green manures and inorganic fertilizers as phosphorus sources for maize in western Kenya. Agrofor Syst 44:21-36

Gruhn P, Goletti F, Yudelman M (2000) Integrated nutrient management, soil fertility, and sustainable agriculture: current issues and future challenges. International Food Policy Research Institute, 2033 K Street, N.W. Washington, D.C. 20006 U.S.A, p 31

Guevarra AB, Whitney AS, Thompson JT (1978) Influence of intra-row spacing and cutting regimes on the growth and yield of Leucaena. Agronomy J 70:1033-1037

Harrington MG (1989) Gambel oak root response to spring, summer, and fall prescribed burning. J Range Manag 42:504-507

Ikerra S, Semu E, Mrema J (2006) Combining T. diversifolia and minjingu phosphate rock for improvement of $\mathrm{P}$ availability and maize grain yields on a chromic acrisol in Morogoro, Tanzania. Nutr Cycl Agroecosyst 76:249-260

Isaac L, Wood CW, Shannon DA (2003) Pruning management effects on soil carbon and nitrogen in contour hedgerow cropping with Leucaena leucocephala (Lam.) De Wit on sloping land in Haiti. Nutr Cycl Agroecosyst 65:253-263

Jama BA, Palm CA, Buresh RJ, Niang AI, Gachengo C, Nziguheba G, Amadalo B (2000) Tithonia diversifolia as a green manure for soil fertility improvement in western Kenya: a review. Agrofor Syst 49:201-202

Kang BT (1991) Soil management and crop production in alley farming. IITA research guide 29. International Institute of Tropical Agriculture (IITA), Ibadan, Nigeria, $26 \mathrm{pp}$

Kang BT (1997) Alley cropping - soil productivity and nutrient recycling. For Ecol Manag 91:75-82

Latt CR (1996) Biomass production in agroforestry trees as influenced by cutting frequency and reserve carbohydrates. $\mathrm{PhD}$ dissertation. University of Florida, Gainesville

Latt CR, Nair PKR, Kang BT (2000) Interactions among cutting frequency, reserve carbohydrates, and post-cutting biomass production in Gliricidia sepium and Leucaena leucocephala. Agrofor Syst 50:27-46

Lin C, Tu S, Huang J, Chen Y (2009) The effect of plant hedgerows on the spatial distribution of soil erosion and soil fertility on sloping farmland in the purple-soil area of China. Soil Tillage Res 105:307-312

Nair PKR, Buresh RJ, Mugendi DN, Latt CR (1999) Nutrient cycling in tropical agroforestry systems: myths and science. In: Buck LE, Lassoie JP, Fernandes ECM (eds) Agroforestry in sustainable agricultural systems. CRC Press/Lewis Publ., Boca Raton, Fl, USA, pp 1-31

Nye PH, Greenland DJ (1960) The soil under shifting cultivation. Commonwealth Agricultural Bureaux, Farnham Royal, England, 144 pp

Nziguheba G, Merckx R, Palm CA, Rao MR (2000) Organic residues affect phosphorus availability and maize yields in a Nitisol of western Kenya. Biol Fertil Soils 32:328-339

Quinkenstein A, Wöllecke J, Böhm C, Grunewald H, Freese D, Schneider BU, Huttl RF (2009) Ecological benefits of the alley cropping agroforestry system in sensitive regions of Europe. Environ Sci Policy 12:1112-1121

Smaling EMA, Nandwa SM, Janssen BH (1997) Soil fertility in Africa is at stake. In: Buresh RJ, Sanchez PA, Calhoun F (eds) Replenishing soil fertility in Africa: SSSA special 
publication number 51. ASA and SSSA, Madison, USA, pp 47-61

VSN International Ltd. (2008) GENSTAT for Windows, 11 edn. VSN International, 5 The Waterhouse, Waterhouse Street, Hemel Hempstead, Hertfordshire HP1 1ES
Wang L, Tang L, Wang X, Chen F (2010) Effects of alley crop planting on soil and nutrient losses in the citrus orchards of the Three Gorges Region. Soil Tillage Res 110:243-250

Young A (1997) Agroforestry for soil management. CAB International, Wallingford, UK, p 320 